\title{
Genotyping of IL-4 -590 (C>T) Gene in Iraqi Asthma Patients
}

\author{
Ihsan A. Hussein and Saddam H. Jaber \\ Department of Biology, College of Education for Pure Science-Ibn Al-Haytham, University of Baghdad, Baghdad, Iraq \\ Correspondence should be addressed to Ihsan A. Hussein; ihsan1964@yahoo.com
}

Received 1 December 2016; Revised 12 February 2017; Accepted 21 February 2017; Published 12 March 2017

Academic Editor: Hubertus Himmerich

Copyright (C) 2017 Ihsan A. Hussein and Saddam H. Jaber. This is an open access article distributed under the Creative Commons Attribution License, which permits unrestricted use, distribution, and reproduction in any medium, provided the original work is properly cited.

\begin{abstract}
This study is the first investigation in Iraq dealing with genotyping of $I L-4-590$ (C>T) gene, especially in Iraqi patients with asthma. We studied forty-eight blood samples collected from patients with asthma and compared with age-matched 25 healthy individuals as controls. The polymorphism results of $I L-4-590(\mathrm{C}>\mathrm{T})$ gene by using amplification refractory mutation system (ARMS-PCR) showed the presence of $C$ and $T$ alleles and three genotypes (CC, CT, and TT). Interestingly the frequency of $C$ allele and CC genotype was higher in patients with asthma in comparison with the same allele and genotype in control $\left(P 1 \times 10^{-6}\right)$. This increase was associated with an increased risk factor of asthma (odds ratio [OR] 9.21; 95\% confidence interval [CI] 3.58-23.71). Genotypes analysis by using Hardy-Weinberg distribution showed no significant differences between patients with asthma and healthy subjects. In conclusion, the increasing risk of asthma was associated with $C$ allele and the CC genotype and these are revealed as etiological fraction with risk by having this disease, while the $T$ allele percentage ratio in controls was higher when it is compared with asthma patients suggesting that these alleles have a protective effect (preventive fraction).
\end{abstract}

\section{Introduction}

Asthma is a complex chronic inflammatory disease that results from the interaction between genetic predisposition and environmental factors [1]. More than 300 million persons worldwide were affected by this airways disease, with approximately 250,000 annual deaths as a result [2]. It has also been estimated that the number of asthmatic patients will increase by 2015 for more than 100 million [3]. Multiple interacting genes have been involved in causing this disease and contributing to the disease pathogenesis and other genes have a protective effect. Each gene may have its own tendency to be influenced by environment factors [4]. However, the identified asthma susceptibility genes have increased rapidly over the last 5 years, especially when genome wide association (GWA) study approach has been applied [1]. Interleukin 4 was originally discovered as a low molecular weight $\mathrm{T}$ cell-derived polypeptide of 129 amino acids, which is encoded by the IL-4 gene located on chromosome 5q23.31: IL-4 [5]. Closer to this chromosomal region (5q31-q33), asthma and atopy susceptibility gene(s) have been mapped by numerous genetic studies in several ethnic populations: Dutch [6,7], Amish [8], American Caucasian [9], Hutterite [10], and British [11, 12].
The role that interleukin- 4 plays in the pathogenesis of asthma has been indicated from actively sensitized IL-4 knockout mice [13, 14]. Studies on T helper 2 (Th2) cytokines in asthma have focused on IL- 4 and IL- 5 and this is due to the crucial role of these two cytokines in Th2 generation responses in a variety of animal models. IL-4 is essential for the maturation of native $\mathrm{T}$ cells toward Th2 cells and production of $\operatorname{IgE}[15,16]$. Polymorphisms in genes play key roles in regulation of cytokines expression; for example, substitution of C by T at the position -590 of IL4 gene has been reported to be associated with a reduced IL4 expression, while the TT genotype upregulated the production of this cytokine [17]. This work is the first investigation in Iraq that dealt with genotyping of $I L 4-590(\mathrm{C}>\mathrm{T})$ in a sample of Iraqi asthmatic patients with the aim to determine its susceptibility role.

\section{Material and Methods}

2.1. Subjects. Forty-eight asthma patients and 25 controls (healthy) subjects were enrolled in the study. The patients were referred to the Al Zahra Center for Allergy and Asthma 
TABLE 1: Primers for $I L-4-590$ (C>T) genotyping.

\begin{tabular}{lcc}
\hline Primer & Sequence $\left(5^{\prime} \rightarrow 3^{\prime}\right)$ & Product size $(\mathrm{bp})$ \\
\hline T allele & $5^{\prime}$-ACACTAAACTTGGGAGAACATTGTT-3 & 216 \\
C allele & $5^{\prime}$-ACACTAAACTTGGGAGAACATTGTC-3 & 248 \\
Reverse & $5^{\prime}$-GAATTTGTTAGTAATGCAGTCCTCC-3' & - \\
\hline
\end{tabular}

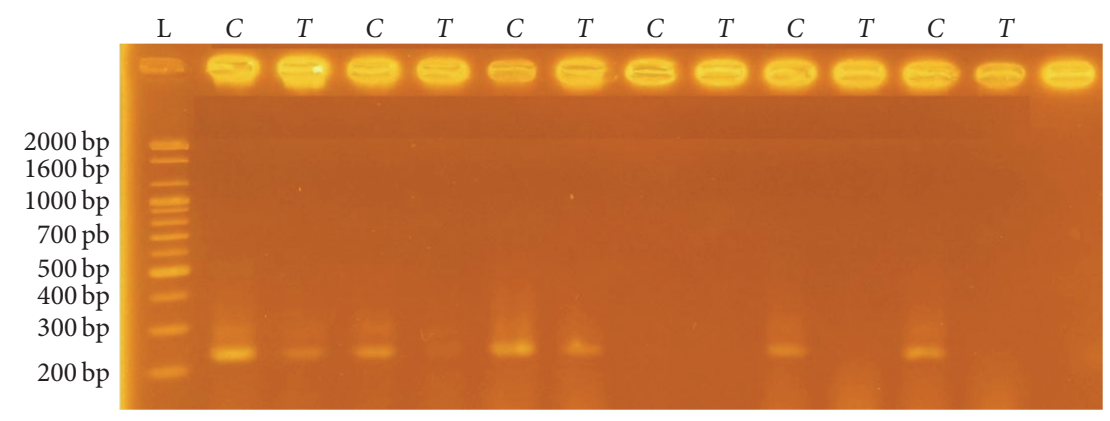

FIGURE 1: Gel electrophoresis for the $I L-4$ gene $-590(\mathrm{C}>\mathrm{T})$ showing the $C$ and $T$ alleles in some asthma patients. (Gel electrophoresis was done by using $1.5 \%$ agarose gel concentration, 75 volts for 2 hours. Presence of one band in $C$ lane and absence of this band in $T$ lane refer to the genotype CC. In contrast, presence of one band in $T$ lane and absence of this band in $C$ lane refer to the genotype TT. Presence of two bands in both lanes refers to the genotype CT.)

TABLE 2: PCR mix reaction for genotyping of $I L-4$ gene position $-590(\mathrm{C}>\mathrm{T})$

\begin{tabular}{lcc}
\hline Component & Volume $(\mu \mathrm{l})$ & $\begin{array}{c}\text { Final } \\
\text { concentration }\end{array}$ \\
\hline $\begin{array}{l}\text { Each primer }(\mathrm{T} \\
\begin{array}{l}\text { or C allele }+ \\
\text { reverse) }\end{array}\end{array}$ & 2 & $1 \mu \mathrm{M}$ \\
$\begin{array}{l}\text { DNA template } \\
\text { Nuclease-free }\end{array}$ & 5 & $100 \mathrm{ng}$ \\
$\begin{array}{l}\text { water } \\
\text { Final volume }\end{array}$ & 11 & - \\
\hline
\end{tabular}

${ }^{*} \mathrm{~T}$ and reverse primers were used for detecting $T$ allele; $C$ and reverse primers were used for detecting $C$ allele.

in Baghdad, Iraq, for diagnosis and treatment. The diagnosis was made by the consultant medical staff according to international criteria. All cases and controls were at the age range 10-65 years. Anticoagulants EDTA tubes were used for collecting the peripheral blood for DNA isolation.

2.2. Genotyping. DNA from venous blood was isolated using ReliaPrep ${ }^{\text {TM }}$ Blood gDNA Miniprep System kit (Promega). The $I L-4$ gene at position $-590(\mathrm{C}>\mathrm{T})$ was genotyped using the amplification refractory mutation system (ARMS-PCR) approach. Primers for this position were used according to [18] and synthesized at Alpha DNA Company (Canada) (Table 1).

2.3. ARMS-PCR. ARMS-PCR approach was used for genotyping of IL4 -590 (C>T). AccuPower ${ }^{\circledR}$ PCR PreMix
(Bioneer, Korea) was prepared according to [18] with some modifications. The primers and DNA template were added to PCR PreMix tubes and the final volume for PCR reaction was made up to $20 \mu \mathrm{L}$ with nuclease-free water (Table 2). The reaction mixers were placed in thermal cycler (Esco, Singapore), and PCR conditions for the all reaction mixers are described in Table 3.

The products of PCR were resolved on 1.5\% agarose gels. The DNA 100 bp ladder (Bioneer, Korea) was also loaded on the agarose gel. Two microliters of bromophenol blue dye was loaded with all reaction mixer samples. The gel electrophoresis was performed by using $75 \mathrm{~V}$ for $2 \mathrm{hrs}$ and stained with ethidium bromide (Promega, USA) for $30 \mathrm{~min}$. The gel was documented with gel documentation system (Biocom, USA).

2.4. Statistical Analysis. Percentage frequencies and significant differences data between patients and controls were given by Fisher's exact test. The odds ratio (OR) and confidence intervals (CI) were analyzed by using Compare 2 Ver.3.04 program designed by J. H. Abramson/2003-2013. Deviations from Hardy-Weinberg were tested using an exact test available at http://www.had2know.com/academics.html.

\section{Results and Discussion}

By using ARMS-PCR, the polymorphism of IL4 -590 (C>T) showed the presence of $C$ and $T$ alleles and three genotypes (CC, CT, and TT) by using the specific $C$, specific $T$, and reverse primers (Figure 1).

Genotype frequencies of IL4-590 (C>T) were in a good agreement with Hardy-Weinberg equilibrium in asthma 
TABLE 3: PCR conditions for genotyping of $I L-4$ gene position $-590(\mathrm{C}>\mathrm{T})$.

\begin{tabular}{|c|c|c|c|}
\hline Steps & \multicolumn{2}{|c|}{ Temperature $\left({ }^{\circ} \mathrm{C}\right)$ and cycles } & Time (sec) \\
\hline Denature template & & & 60 \\
\hline First initial denaturation & 95 & & 15 \\
\hline First annealing & 65 & 10 cycles & 50 \\
\hline First extension & 72 & & 40 \\
\hline Second initial denaturation & 95 & & 50 \\
\hline Second annealing & 59 & 20 cycles & 50 \\
\hline Second extension & 72 & & 50 \\
\hline Final extension & & & $7 \mathrm{~min}$ \\
\hline Incubation & & & $5 \mathrm{~min}$ \\
\hline
\end{tabular}

TABLE 4: Hardy-Weinberg distribution of IL4 -590 (C>T) genotypes in asthma patients and controls.

\begin{tabular}{|c|c|c|c|c|c|}
\hline Gene & Genotype & $\begin{array}{l}\text { Observed asthma } \\
\text { patients number } \\
(\%)\end{array}$ & $\begin{array}{l}\text { Expected asthma } \\
\text { patients number } \\
(\%)\end{array}$ & $\begin{array}{c}\text { Observed } \\
\text { controls number } \\
(\%)\end{array}$ & $\begin{array}{c}\text { Expected } \\
\text { controls number } \\
(\%)\end{array}$ \\
\hline \multirow{4}{*}{$\begin{array}{l}I L-4-590 \\
(\mathrm{C}>\mathrm{T})\end{array}$} & $\mathrm{CC}$ & $42(87.5)$ & $(85.95) 41.26$ & $8(32)$ & (33.64) 8.41 \\
\hline & CT & $5(10.42)$ & (13.52) 6.49 & $13(52)$ & (48.72) 12.18 \\
\hline & TT & $1(2.08)$ & (0.53) 0.26 & $4(16)$ & (\%17.64) 4.41 \\
\hline & $P$ value & \multicolumn{2}{|c|}{0.1118} & \multicolumn{2}{|c|}{0.7364} \\
\hline
\end{tabular}

TABLE 5: Allele frequencies of IL4 $-590(\mathrm{C}>\mathrm{T})$ in asthma patients and controls.

\begin{tabular}{lcccc}
\hline Gene position & Allele & Asthma patients number $(\%)$ & Controls number (\%) & OR (95\% CI) \\
\hline & $C$ & $(92.71) 89$ & $(58) 29$ & $9.21(\mathrm{IC}=3.58-23.71)$ \\
$I L-4-590(\mathrm{C}>\mathrm{T})$ & $\mathrm{EF}$ & $(7.29) 7$ & 0.826 & $1 \times 10^{-6^{*}}$ \\
& $T$ & & $(42) 21$ & $0.11(\mathrm{IC}=0.04-0.28)$ \\
& PF & & 0.374 & $1 \times 10^{-6^{*}}$ \\
\hline
\end{tabular}

$\mathrm{OR}=$ odds ratio, $\mathrm{CI}=$ confidence intervals, $\mathrm{EF}=$ etiological fraction, and $\mathrm{PF}=$ preventive fraction. ${ }^{*}$ Significant differences at $P<0.05$ level by using Fisher's test.

TABLE 6: Frequency distribution of $I L 4-590$ (C>T) genotypes in asthma patients and controls.

\begin{tabular}{lcccc}
\hline Gene & Genotype & Asthma patients number $(\%)$ & Controls number $(\%)$ & OR $(95 \%$ CI $)$ \\
\hline & CC & $42(87.5)$ & $8(32)$ & $14.88(\mathrm{IC}=4.57-48.45)$ \\
& EF & & 0.816 & $2.5 \times 10^{-6}$ \\
$I L-4-590(\mathrm{C}>\mathrm{T})$ & CT & $5(10.42)$ & $13(52)$ & $0.11(\mathrm{IC}=0.03-0.35)$ \\
& PF & & 0.464 & $3.1 \times 10^{-4}$ \\
& TT & $1(2.08)$ & $4(16)$ & $0.11(\mathrm{IC}=0.01-1.03)$ \\
& & & 0.142 & 0.044 \\
\hline
\end{tabular}

$\mathrm{OR}=$ odds ratio, $\mathrm{CI}=$ confidence intervals, $\mathrm{EF}=$ etiological fraction, and $\mathrm{PF}=$ preventive fraction.

patients and controls, as there were no significant differences between observed and expected genotype frequencies (Table 4).

The $C$ allele showed a significant increased frequency in patients compared to controls (92.71 versus 58\%). In contrast, the $T$ allele frequency was significantly higher in controls (42\%) than in patients (7.29\%). The OR for $C$ and $T$ alleles were 9.21 and 0.11 , respectively. Such results suggest that $C$ allele has a predisposing effect, while $T$ allele has a protective effect (Table 5). In terms of genotype frequencies, CC genotype was observed to have a significant increased frequency in patients compared to controls (87.5 versus $32 \%$ ), while CT and TT genotype frequencies were significantly decreased in patients $(10.42 \%$ and $2.08 \%$, respectively) compared to controls (52\% and $16 \%$, respectively). The OR for CC, CT, and TT genotypes was $14.88,0.11$, and 0.11 , respectively (Table 6). 
An increased risk of asthma might be associated with CC genotype, while the genotypes $\mathrm{CT}$ and TT are thought to have a protective effect from asthma.

Studies of candidate-genes have examined the involvement of many genes in asthma and allergy and demonstrated a role for more than 100 loci. Several themes that regard biology and pathogenesis of these diseases have elucidated by these studies. Traditional linkage analyses revealed a small number of genes that are associated with asthma or allergy [19].

Cytokines are key mediators that regulate innate and adaptive immune responses, which are also subjected to the effect of factors such as infection, inflammation, and hormonal condition. However, cytokine gene polymorphisms have a role in the expression of cytokines by immune cells [20]. The $C$ allele frequency in asthma patients was higher in comparison with $T$ allele and this refers to the role of CC genotype in the development of the disease, but these results need more evidences for confirming and also need more immunological studies such as detecting the level of IL-4 in sera of asthma patients. In a Dutch study of genegene interaction in asthma, Howard et al. [21] observed significant associations of atopy and asthma with several IL4RA polymorphisms, including S478P and total serum IgE levels $(P=0.0007)$. A further study carried out by Xiaoyan et al. [22] investigated six gene loci (one of them is of IL4590), and the authors suggested that these genes make little contribution to the development of asthma in children of Chinese Han nationality.

\section{Conclusions}

In conclusion, the increasing risk of asthma was associated with $C$ allele and the CC genotype, while the $T$ allele and $\mathrm{CT}$ and TT genotypes were present more in healthy subjects which are thought to have a protective effect (preventive fraction). These alleles dominating in special population compared to others at genetic levels could be used as an indicator of genetic biomarkers that effect on either pathogenesis or protection from the diseases.

\section{Conflicts of Interest}

The authors (Ihsan A. Hussein and Saddam H. Jaber) declare that there are no conflicts of interest regarding the publication of this paper.

\section{References}

[1] N. S. Grotenboer, M. E. Ketelaar, G. H. Koppelman, and M. C. Nawijn, "Decoding asthma: translating genetic variation in IL33 and IL1RL1 into disease pathophysiology," The Journal of Allergy and Clinical Immunology, vol. 131, no. 3, pp. 856-865.e9, 2013.

[2] J. Bousquet, T. J. H. Clark, S. Hurd et al., "GINA guidelines on asthma and beyond," Allergy, vol. 62, no. 2, pp. 102-112, 2007.

[3] M. Masoli, D. Fabian, S. Holt, and R. Beasley, "The global burden of asthma: executive summary of the GINA dissemination committee report," Allergy: European Journal of Allergy and Clinical Immunology, vol. 59, no. 5, pp. 469-478, 2004.
[4] M. Bijanzadeh, P. A. Mahesh, and N. B. Ramachandra, "An understanding of the genetic basis of asthma," Indian Journal of Medical Research, vol. 134, no. 8, pp. 149-161, 2011.

[5] D. Voehringer, T. A. Reese, X. Huang, K. Shinkai, and R. M. Locksley, "Type 2 immunity is controlled by IL-4/IL-13 expression in hematopoietic non-eosinophil cells of the innate immune system," Journal of Experimental Medicine, vol. 203, no. 6, pp. 1435-1446, 2006.

[6] D. A. Meyers, D. S. Postma, C. I. M. Panhuysen et al., "Evidence for a locus regulating total serum IgE levels mapping to chromosome 5," Genomics, vol. 23, no. 2, pp. 464-470, 1994.

[7] D. S. Postma, E. R. Bleecker, P. J. Amelung et al., "Genetic susceptibility to asthma-bronchial hyperresponsiveness coinherited with a major gene for atopy," New England Journal of Medicine, vol. 333, no. 14, pp. 894-900, 1995.

[8] D. G. Marsh, J. D. Neely, D. R. Breazeale et al., "Linkage analysis of IL4 and other chromosome 5q31.1 markers and total serum immunoglobulin E concentrations," Science, vol. 264, no. 5162, pp. 1152-1156, 1994.

[9] Collaborative Study of the Genetics of Asthma (CSGA), "A genome wide search for asthma susceptibility loci in ethnically diverse populations," Nature Genetics, vol. 15, no. 4, pp. 389-397, 1997.

[10] C. Ober, N. J. Cox, M. Abney et al., "Genome-wide search for asthma susceptibility loci in a founder population," Human Molecular Genetics, vol. 7, no. 9, pp. 1393-1398, 1998.

[11] I. J. M. Doull, S. Lawrence, M. Watson et al., "Allelic association of gene markers on chromosomes $5 \mathrm{q}$ and $11 \mathrm{q}$ with atopy and bronchial hyperresponsiveness," American Journal of Respiratory and Critical Care Medicine, vol. 153, no. 4, 1996.

[12] C. Lonjou, K. Barnes, H. Chen et al., "A first trial of retrospective collaboration for positional cloning in complex inheritance: assay of the cytokine region on chromosome 5 by the Consortium on Asthma Genetics (COAG)," Proceedings of the National Academy of Sciences of the United States of America, vol. 97, no. 20, pp. 10942-10947, 2000.

[13] G. G. Brusselle, J. C. Kips, J. H. Tavernier et al., "Attenuation of allergic airway inflammation in IL-4 deficient mice," Clinical and Experimental Allergy, vol. 24, no. 1, pp. 73-80, 1994.

[14] G. Brusselle, J. Kips, G. Joos, H. Bluethmann, and R. Pauwels, "Allergen-induced airway inflammation and bronchial responsiveness in wild-type and interleukin-4-deficient mice," American journal of respiratory cell and molecular biology, vol. 12, no. 3, pp. 254-259, 1995.

[15] K. Nelms, A. D. Keegan, J. Zamorano, J. J. Ryan, and W. E. Paul, "The IL-4 receptor: signaling mechanisms and biologic functions," Annual Review of Immunology, vol. 17, pp. 701-738, 1999.

[16] T. Shirakawa, K. A. Deichmann, K. Izuhara, X.-Q. Mao, C. N. Adra, and J. M. Hopkin, "Atopy and asthma: genetic variants of IL-4 and IL-13 signalling," Immunology Today, vol. 21, no. 2, pp. 60-64, 2000.

[17] E. Kamali-Sarvestani, J. Zolghadri, B. Gharesi-Fard, and J. Sarvari, "Cytokine gene polymorphisms and susceptibility to recurrent pregnancy loss in Iranian women," Journal of Reproductive Immunology, vol. 65, no. 2, pp. 171-178, 2005.

[18] A. Alsaid, M. El-Missiry, E.-S. Hatata, M. Tarabay, and A. Settin, "Association of $I L-4-590 \mathrm{C}>\mathrm{T}$ and $I L-13-1112 \mathrm{C}>\mathrm{T}$ gene polymorphisms with the susceptibility to Type 2 diabetes mellitus," Disease Markers, vol. 35, no. 4, pp. 243-247, 2013.

[19] M. E. March, P. M. A. Sleiman, and H. Hakonarson, "Genetic polymorphisms and associated susceptibility to asthma," International Journal of General Medicine, vol. 6, pp. 253-265, 2013. 
[20] M. K. Arababadi, A. A. Pourfathollah, S. Daneshmandi et al., "Evaluation of relation between IL- 4 and IFN- $\gamma$ polymorphisms and type 2 diabetes," Iranian Journal of Basic Medical Sciences, vol. 12, no. 2, pp. 100-104, 2009.

[21] T. D. Howard, G. H. Koppelman, J. Xu et al., "Gene-gene interaction in asthma: IL4RA and IL13 in a Dutch population with asthma," American Journal of Human Genetics, vol. 70, no. 1, pp. 230-236, 2002.

[22] H. L. Xiaoyan, L. Quanhua, L. Jie, and B. Yixiao, "Singlenucleotide polymorphisms in genes predisposing to asthma in children of Chinese Han nationality," Journal of Investigational Allergology Clinical Immunology, vol. 19, no. 5, pp. 391-395, 2009. 


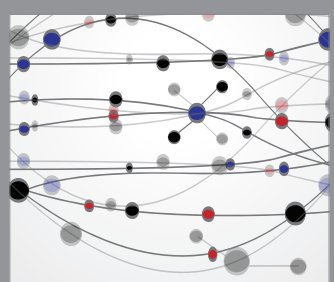

The Scientific World Journal
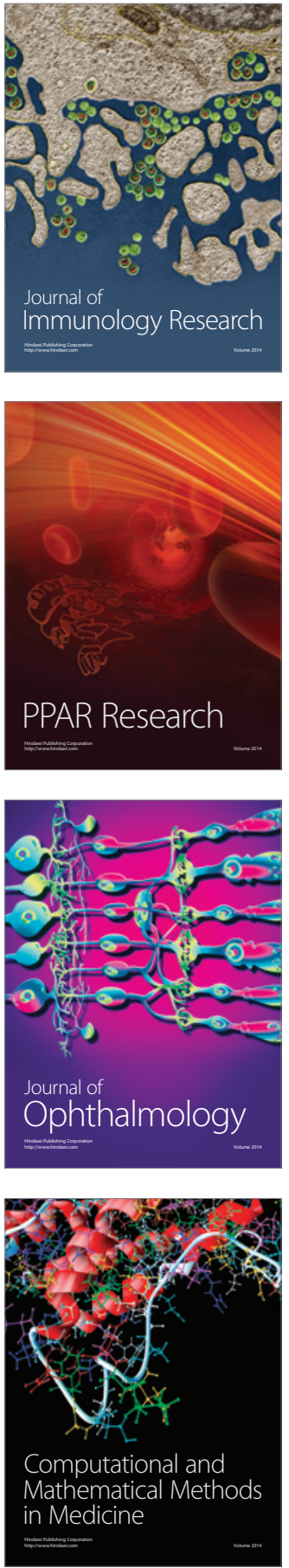

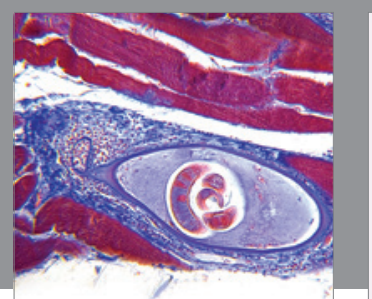

Gastroenterology Research and Practice
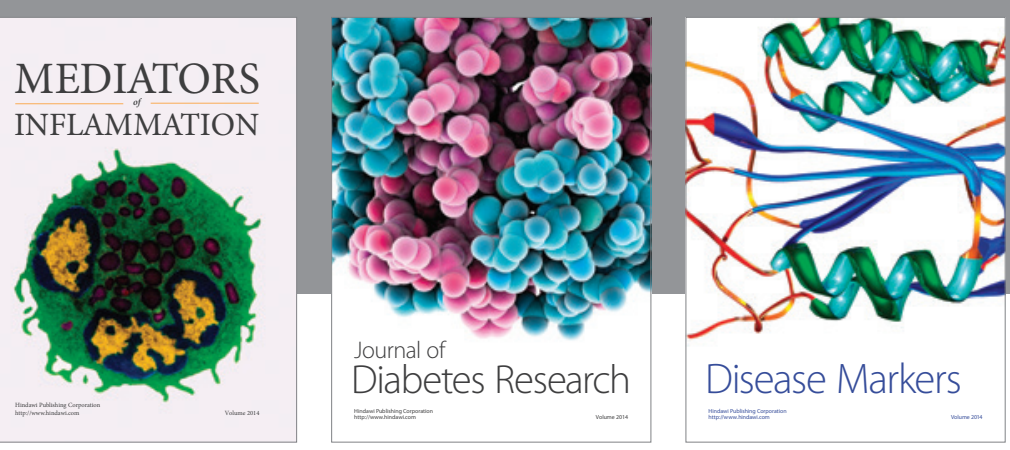

Disease Markers

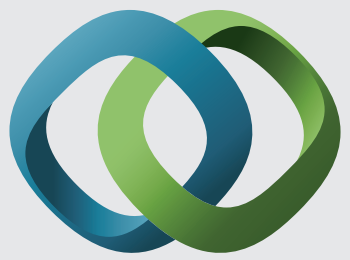

\section{Hindawi}

Submit your manuscripts at

https://www.hindawi.com
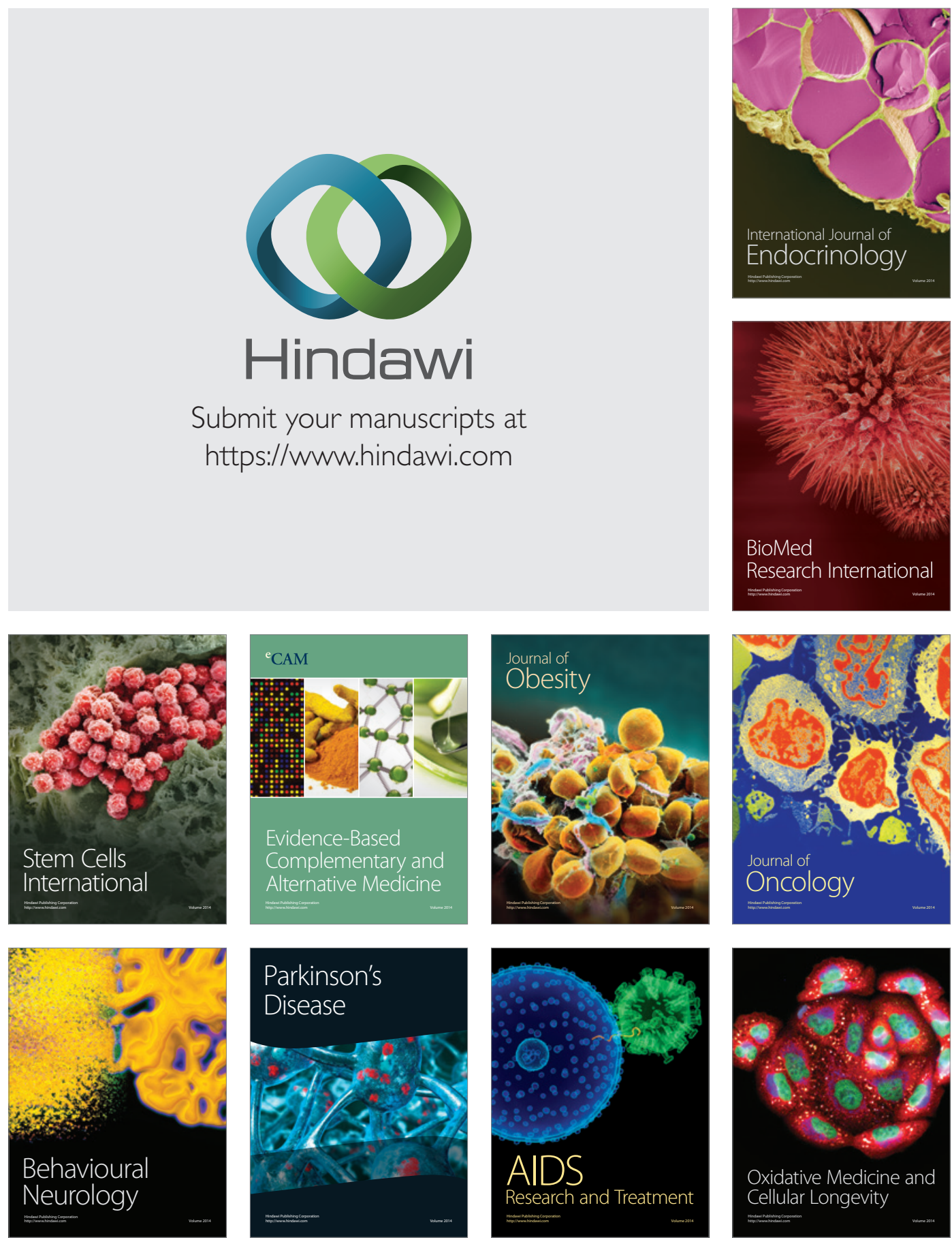